\title{
Impact of Foreign Direct Investment, Trade Openness, Domestic Demand, and Exchange Rate on the Export Performance of Bangladesh: A VEC Approach
}

\author{
Bishnu Kumar Adhikary \\ College of International Management, Ritsumeikan Asia Pacific University, 1-1 Jumonjibaru, Bepp-hi, Oita-ken, Japan \\ Correspondence should be addressed to Bishnu Kumar Adhikary, adhikary@apu.ac.jp
}

Received 29 March 2012; Revised 16 September 2012; Accepted 16 September 2012

Academic Editor: James E. Payne

Copyright ( 2012 Bishnu Kumar Adhikary. This is an open access article distributed under the Creative Commons Attribution License, which permits unrestricted use, distribution, and reproduction in any medium, provided the original work is properly cited.

This paper investigates the impact of foreign direct investment (FDI), trade openness, domestic demand, and exchange rate on the export performance of Bangladesh over the period of 1980-2009 using the vector error correction (VEC) model under the time series framework. The stationarity of the variables is checked both at the intercept and intercept plus trend regression forms under the ADF and PP stationarity tests. The Johansen-Juselius procedure is applied to test the cointegration relationship between variables followed by the VEC regression model. The empirical results trace a long-run equilibrium relationship in the variables. FDI is found to be an important factor in explaining the changes in exports both in the short run and long-run. However, the study does not trace any significant causal relationship for the cases of trade openness, domestic demand, and exchange rate. The study concludes that Bangladesh should formulate FDI-led polices to enhance its exports.

\section{Motivation}

Although the global financial meltdown curtailed the share of world's foreign direct investment (FDI) into the developed economies to $50.79 \%$ in 2009 from its peak at $86.13 \%$ in 1980 , the share of developing economies increased substantially during the same time, from $13.83 \%$ in 1980 to $48.93 \%$ in 2009 (Figure 1). Similarly, the participation of developing economies in world's exports increased considerably from $26.56 \%$ in 1990 to $32.54 \%$ in 2000 , leveling off at $39.89 \%$ in 2007 , while the same index decreased for the industrialized economies from $72.11 \%$ in 1990 to $58.95 \%$ in 2007 (Figure 2). These facts, in general, motivate to investigate the FDI-export relationship of a developing economy.

Bangladesh, being a member of the developing economies, deserves attention. Since the early 1980s, Bangladesh adopted the "export-led growth" model by changing its import-substitution-led industrial growth model to resolve macroeconomic problems such as a trade deficit, unemployment, and a low foreign exchange reserve. As a major vehicle of the export-led growth model, the government enacted the
Foreign Private Investment (Promotion and Protection) Act in 1980 to provide a legal protection for FDI supplied in Bangladesh against state expropriation and nationalization. To boost exports and to provide a congenial investment climate free from bureaucracy and institutional bottlenecks, the government established several Export Processing Zones (EPZs) in the 1980s. Simultaneously, the government pursued greater trade liberalization policy by introducing various fiscal and nonfiscal incentives to lure FDI. In addition, the government gradually lifted restrictions on repatriation of capital and profits and unleashed almost all industrial sectors for foreigners investing independently or jointly with local partners [1]. These incentives and facilities together with a low labor cost structure and reasonable GDP growth rate $(5 \%$ on average since 1990) made Bangladesh a resilient and attractive investment destination for foreign investment since the late 1980s.

Figure 3 presents the decade-wise average performance of exports, FDI, trade openness, exchange rate, and domestic demand in Bangladesh over the period of 1980-2009. It shows that the average exports (expressed as the value of 
FDI distribution between developed and developing economies (\% of total world)

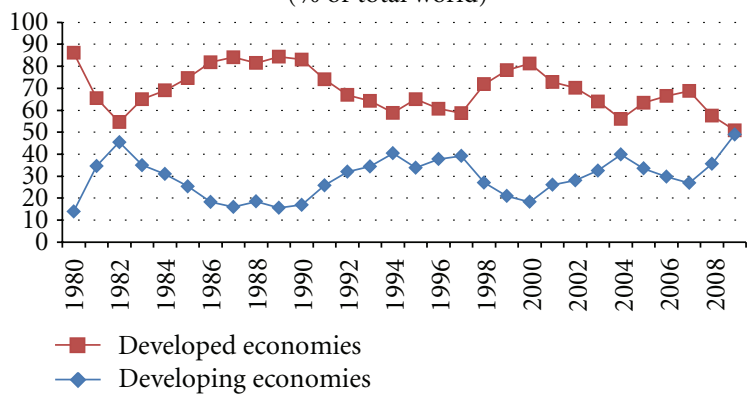

FIgURE 1: Decade-wise average trend in exports, FDI, exchange rate, trade openness, and domestic demand in Bangladesh. Source: constructed by author from the WDI database 2010.

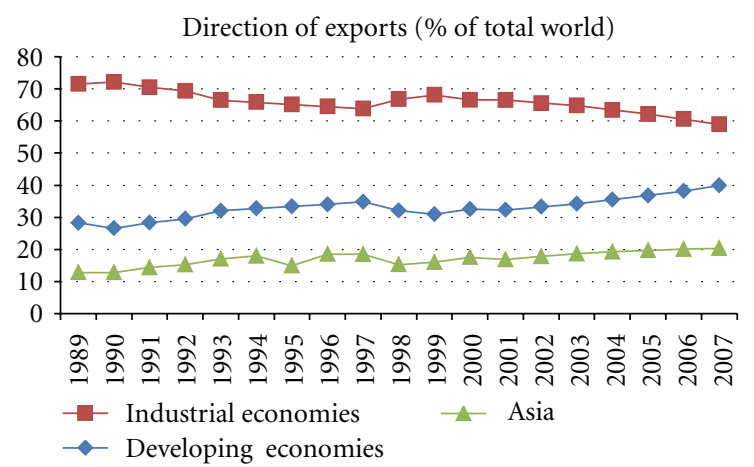

FIgURE 2: FDI Distribution between developed and developing economies (1980-2009). Constructed by author from the WDI database 2010 World Bank.

exports over GDP) in Bangladesh increased from 5.24\% in the 1980 s to $16.99 \%$ in the 2000 s, and the decadewise average performance of FDI (expressed as a percentage of GDP) increased from $0.01 \%$ in the 1980 s to $1.02 \%$ in the 2000s. Likewise, the average economic openness, measured by the trade over GDP, increased significantly during the previous three decades, from $19.23 \%$ in the $1980 \mathrm{~s}$ to $40.48 \%$ in the 2000 s. Conversely, the average domestic demand (measured by the government expenditure over GDP) remained almost constant at $4.52 \%$ in the decades of the 1980s and the 1990s, although it increased slightly to $5.20 \%$ in the 2000s. Importantly, the relative strength of the domestic currency, Bangladeshi Taka (BDT), in terms of the US dollar decreased by almost two and a half times during the last three decades, from BDT 25.89 per dollar in the 1980 s to BDT 62.33 in the 2000s. As a whole, the positive trend of FDI, exports, domestic demand, trade openness, and exchange rate confirms that Bangladesh has adopted an export-led growth model by encouraging FDI, opening up the domestic market, and devaluing currency.

However, Figure 3 leaves two basic questions for investigation. First, is there a long-term equilibrium link between FDI, economic openness, exchange rate, domestic demand, and export performance in the context of Bangladesh?

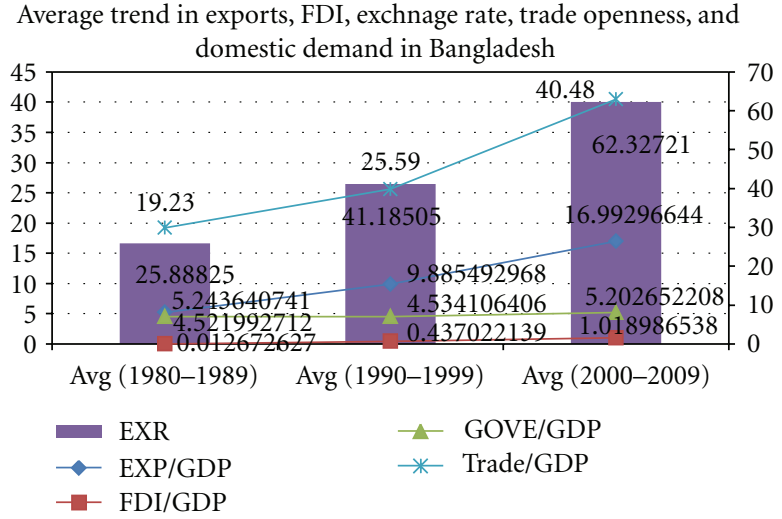

Figure 3: Direction of world exports (1989-2007). Constructed by author from the direction of trade statistics year book, IMF 2007.

Second, is the link unidirectional or bidirectional? This paper attempts to address these questions empirically.

The remainder of the paper proceeds as follows: Section 2 provides a brief survey of the empirical literature on the link between FDI, trade openness, exchange rate, domestic consumption, and exports. Section 3 describes data and methodology of the study. Section 4 presents and analyzes the empirical results. Section 5 concludes and outlines some policy issues.

\section{A Brief Survey of Empirical Literature}

The empirical works on the link between FDI, trade openness, exchange rate, domestic demand, and exports tend to be confounding. For instance, a positive relationship between trade openness and exports performance was documented by Papageorgiou [2], Weiss [3], Santos-Paulino [4], Ahmed [5], Niemi [6], and Babatunde [7], while a negative link was reported by Agosín [8], Greenaway and Sapsford [9], Shafaeddin [10], Moon [11], and Morrissey and Andrew [12]. Likewise, a positive link between FDI and export was reported by Dritsaki et al. [13], Sharma [14], Liu et al. [15], Xing [16], and Xuan and Xing [17], whereas, Sevensson [18] documented a negative association between them. In addition, Petri et al. [19] and F. S. T Hsiao and M. C. W Hsiao [20] unveiled an insignificant relationship between them. Similarly, the relationship found between exchange rates and exports in empirical literature is highly controversial. For Instance, Arizie-Oskooee and Ltaifa [21], and Arize et al. [22] reported a negative relationship between exchange rate volatility and exports performance, while Bailey et al. [23], Assery and Peel [24], and Abbott et al. [25] did not trace any link between them; however, Wong and Tang [26] documented a positive association. By the same token, ADB [27] reported a negative association between exports and growth rate of domestic demand in the southeast Asian countries, whereas Lai [28] reported a short-run bilateral causal connection between them. Table 1 presents a summary of recent empirical studies that investigated the long-run relationship between FDI, trade openness, domestic demand, exchange rate, and exports using different estimation models. These 
TABLE 1: A Brief summary of recent studies.

\begin{tabular}{|c|c|c|c|}
\hline Author(s) and date & Variable used & Country, coverage, and method & Findings \\
\hline $\begin{array}{l}\text { Chimobi and Uche, } \\
2010 \text { [47] }\end{array}$ & $\begin{array}{l}\text { Gov't consumption, household } \\
\text { consumption, real GDP, and } \\
\text { export }\end{array}$ & $\begin{array}{l}\text { Nigeria; annual data (1970-2005); } \\
\text { VAR }\end{array}$ & $\begin{array}{l}\text { (i) No long-run equilibrium relationship } \\
\text { (ii) Export causes domestic demand } \\
\text { (iii) Bilateral causality between export } \\
\text { and household consumption }\end{array}$ \\
\hline Prasanna, $2010[48]$ & $\begin{array}{l}\text { Inward FDI, total manufactured } \\
\text { exports, high technology } \\
\text { manufactured exports, and } \\
\text { manufacturing value added }\end{array}$ & $\begin{array}{l}\text { India; annual data } \\
(1991-92-2006-07) ; \text { OLS }\end{array}$ & FDI significantly influences exports \\
\hline $\begin{array}{l}\text { Martinez-Martin, } 2010 \\
{[49]}\end{array}$ & $\begin{array}{l}\text { FDI, exports, domestic income, } \\
\text { world income, and } \\
\text { competitiveness }\end{array}$ & $\begin{array}{l}\text { Spain; annual data (1993-2008); } \\
\text { VECM }\end{array}$ & $\begin{array}{l}\text { A positive Granger causality runs from } \\
\text { FDI to exports in the long-run }\end{array}$ \\
\hline Duasa, 2009 [50] & $\begin{array}{l}\text { Volume of exports and imports, } \\
\text { REER, and trade balance }\end{array}$ & $\begin{array}{l}\text { Malaysia; annual data } \\
\text { (1999-2006); TAR and M-TAR }\end{array}$ & $\begin{array}{l}\text { A long-run asymmetric cointegration } \\
\text { exists between REER and exports }\end{array}$ \\
\hline Babatunde, 2009 [7] & $\begin{array}{l}\text { Merchandise exports, REER, } \\
\text { average tariff rate, exchange rate, } \\
\text { and imports of raw material }\end{array}$ & $\begin{array}{l}\text { Sub-Saharan Africa; annual data } \\
\text { (1980-2005); panel-fixed effect } \\
\text { and random effect }\end{array}$ & REER stimulates exports \\
\hline Njong, 2008 [51] & $\begin{array}{l}\text { Real exports, real GDP, REER, } \\
\text { import over total international } \\
\text { trade, export over total } \\
\text { international trade, lag exports, } \\
\text { and lag FDI stock }\end{array}$ & $\begin{array}{l}\text { Cameroon; annual data } \\
(1980-2003) ; A R(p)\end{array}$ & $\begin{array}{l}\text { FDI and REER significantly influence } \\
\text { exports }\end{array}$ \\
\hline Wong, 2008 [52] & $\begin{array}{l}\text { GDP per capita, exports, private } \\
\text { consumption, government } \\
\text { consumption, and investment }\end{array}$ & $\begin{array}{l}\text { ASEAN 5; annual data } \\
\text { (1960-1996); error correction, } \\
\text { Granger causality }\end{array}$ & $\begin{array}{l}\text { (i) A long-run relationship exists } \\
\text { between variables } \\
\text { (ii) Bidirectional Granger causality } \\
\text { between exports and GDP; private } \\
\text { consumption and GDP per capita }\end{array}$ \\
\hline $\begin{array}{l}\text { Mortaza and Narayan, } \\
2007[53]\end{array}$ & $\begin{array}{l}\text { FDI inflows, import and export } \\
\text { over GDP, M2/GDP, literacy rate, } \\
\text { and domestic investment and } \\
\text { inflation }\end{array}$ & $\begin{array}{l}\text { Bangladesh, India, Pakistan, Sri } \\
\text { Lanka, and Nepal; annual data } \\
\text { (1980-2004); VAR, panel-fixed } \\
\text { effect, and random effect }\end{array}$ & $\begin{array}{l}\text { Unidirectional relationship between FDI, } \\
\text { trade liberalization and economic } \\
\text { growth for Bangladesh and Pakistan }\end{array}$ \\
\hline $\begin{array}{l}\text { F. S. T. Hsiao and M. C. } \\
\text { W. Hsiao, } 2006 \text { [20] }\end{array}$ & $\begin{array}{l}\text { Real FDI inflows, real GDP per } \\
\text { capita, and real exports }\end{array}$ & $\begin{array}{l}\text { China, Korea, Hong Kong, } \\
\text { Singapore, Taiwan, Malaysia, } \\
\text { Thailand, and the Philippines; } \\
\text { annual data (1986-2004); panel } \\
\text { VAR }\end{array}$ & $\begin{array}{l}\text { Bidirectional causality between exports } \\
\text { and GDP }\end{array}$ \\
\hline Sahoo, 2006 [35] & $\begin{array}{l}\text { FDI, world income growth, } \\
\text { infrastructure index, domestic } \\
\text { demand, exports, REER, and } \\
\text { GDP growth }\end{array}$ & $\begin{array}{l}\text { Bangladesh, India, Pakistan, Sri } \\
\text { Lanka, and Nepal; annual data } \\
\text { (1975-2003); panel-fixed effect }\end{array}$ & FDI positively influences exports \\
\hline Arize, 1995 [21] & $\begin{array}{l}\text { Log real exports, log REER, and } \\
\text { log real foreign income }\end{array}$ & $\begin{array}{l}\text { USA; monthly data } \\
(1971: 2-1991: 3) \text {; error } \\
\text { correction, ARCH, and linear } \\
\text { moment }\end{array}$ & $\begin{array}{l}\text { (i) A long-run equilibrium relationship } \\
\text { exists. } \\
\text { (ii) Exchange rates and exports are } \\
\text { negatively associated }\end{array}$ \\
\hline
\end{tabular}

studies also present conflicting results, as some authors traced a long-run equilibrium relationship in the variables, whereas others reported a very weak or no relationship at all. Moreover, some authors documented a bidirectional causal relationship, whereas others reported unidirectional causality or no causal relationship in the variables of their studies.

To sum up, empirical studies do not have consensus over the relationship between FDI, trade openness, domestic demand, exchange rate, and exports. These nonconsensus views are primarily attributed to the authors' perspectives, sample selection, measurement of variables, inclusion of other variables, econometric models, and analytical tools applied in studies [20,29]. Besides, the country-specific characteristics such as the degree of technological, economical, infrastructural, and institutional developments are responsible to have these controversial results. Thus, this paper aims at accumulating empirical knowledge by investigating 
the nexus between FDI, trade openness, domestic demand, exchange rate, and exports in the context of Bangladesh, which is a growing economy in South Asia.

\section{Data Description and Methodology}

The paper attempts to trace the long-run equilibrium relationship between FDI, trade openness, domestic demand, exchange rate, and exports of Bangladesh over the period of 1980-2009 using the time series framework. In doing so, the study measures FDI as a percentage of GDP following Nath [30], Asiedu [31], and Tsai [32]. For the measurement of trade openness, a number of measures are used in empirical literature, including the trade volume over GDP, import over GDP, average tariff rate, total taxes on international trade, population densities, and so on. However, the data on tariffs and taxes on international trade are not available in the context of Bangladesh. On the other hand, it is not logical to consider trade volume-related measures of openness for this study, as it uses exports as a dependent variable. Yanikkaya [33] argued that population density can be used as a measure of trade openness, as countries with higher densities tend to have more international contacts. Thus, the density of population (population per square kilometer) as an indicator of trade openness has been taken into account following Yanikkaya [33] and Sachs and Andrew [34]. Domestic demand has been proxied by the government final consumption over GDP following Sahoo [35]. Considering the fact that Bangladesh conducts major exports in the US dollar, the exchange rate has been indexed by Bangladeshi Taka (BDT) per US dollar. Finally, the export of goods and services as a percentage of GDP has been considered as the proxy to exports. All data have been obtained from the database of the World Development Indicators (World Bank) and the Direction of Trade Statistics (International Monetary Fund); the sample covers thirty annual observations.

It is worthwhile to note that the data set of this study is not free from small sample bias, which may result in inefficient estimates of the parameters. One strategy to remove the small sample bias is to consider monthly, quarterly, or semiannual data. However, such forms of data for FDI were not available for Bangladesh before the year 1995. In addition, Beck and Levine [36] doubt that the use of quarterly data produces any better result over annual data. Therefore, this study uses annual data from the year 1980 in order to cover the reform period of FDI and expects that thirty yearly observations would be reasonable for Bangladesh, which got independence in 1971.

The empirical estimation of the study proceeds as follows. It begins with checking the normality of distribution by invoking the Jarque-Bera test. Next, it proceeds to detect the presence of unit root under a univariate analysis by employing both the Augmented Dickey-Fuller (ADF) (following $[37,38]$ ) and the Phillips-Perron (PP) tests (following [39]). The advantage of the PP test over the ADF test is that the PP test takes into account the serial correlations by making corrections to the $t$-statistics of the coefficients of the lagged variables, not by adding the differenced term of the lagged variables. The unit root test has been conducted both at the intercept and intercept plus trend regression forms. In the event of stationarity of each variable at the level test, an Ordinary Least Square (OLS) regression would be run, as given in

$$
\begin{aligned}
\mathrm{EXPG}_{t}= & \alpha+\beta \mathrm{FDIG}_{t}+\Omega \mathrm{PDEN}_{t}-\Psi_{\mathrm{GFCG}} \\
& +\zeta \mathrm{EXR}_{t}+\varepsilon_{t}
\end{aligned}
$$

where EXPG represents export of goods and services over GDP, FDIG represents foreign direct investment as a percentage of GDP, PDEN represents population density, GFCG represents government final consumption over GDP, and EXR represents the exchange rate of the domestic currency over the US dollar. The disturbance term $(\varepsilon)$ is assumed to be independently and identically distributed. The subscript $(t)$ denotes time.

Next, when all the variables are found stationary and integrated in the same order, the dynamic relationship of the variables can be studied by employing the simple Vector Autoregressive (VAR) model, as given in (2) in a matrix form. However, if the series are found not integrated in the same order, the dynamic relationship of the variables needs to be studied using an autoregressive distributed lag model (ARDL) to avoid spurious relationship

$$
\begin{gathered}
{\left[\begin{array}{c}
\mathrm{EXPG}_{t} \\
\mathrm{FDIG}_{t} \\
\mathrm{PDEN}_{t} \\
\mathrm{GFCG}_{t} \\
\mathrm{EXR}_{t}
\end{array}\right]=\alpha_{0}+\alpha_{1}\left[\begin{array}{c}
\mathrm{EXPG}_{t-1} \\
\mathrm{FDIG}_{t-1} \\
\mathrm{PDEN}_{t-1} \\
\mathrm{GFCG}_{t-1} \\
\mathrm{EXR}_{t-1}
\end{array}\right]+\alpha_{2}\left[\begin{array}{c}
\mathrm{EXPG}_{t-2} \\
\mathrm{FDIG}_{t-2} \\
\mathrm{PDEN}_{t-2} \\
\mathrm{GFCG}_{t-2} \\
\mathrm{EXR}_{t-2}
\end{array}\right]} \\
+\cdots+\alpha_{n}\left[\begin{array}{c}
\mathrm{EXPG}_{t-n} \\
\mathrm{FDIG}_{t-n} \\
\mathrm{PDEN}_{t-n} \\
\mathrm{GFCG}_{t-n} \\
\mathrm{EXR}_{t-n}
\end{array}\right]+\varepsilon_{t} .
\end{gathered}
$$

After confirming the stationarity of the variables, the study proceeds to trace cointegration relationship between variables by applying the Johansen-Juselius procedure (following [40-42]). It must be noted that in order to run the Johansen cointegration test, all the series under study must be integrated in the same order, either in a level or in a differenced form. This implies that the difference between two or more nonstationary series becomes stationary when they move together in the long-run, even though they may drift apart in the short run. The maximum eigenvalue $\left(\lambda_{\max }\right)$ and the trace $\left(\lambda_{\text {trace }}\right)$ tests are used to detect a cointegrating vector. These are computed as follows:

$$
\lambda_{\max }=-T \log \left(1-\lambda_{r+1}\right),
$$

where the appropriate null is $r=g$ cointegrating vectors with $(g=0,1,2,3, \ldots)$ against the alternative that $r \leq g+1$

$$
\lambda_{\text {trace }}=-T \sum_{i=r+1}^{k} \log \left(1-\lambda_{i}\right),
$$

where the null is $r=g$ against the more general alternative $r \leq 1$. 
It must be noted that in the presence of one or more cointegrating vectors, the simple VAR method does not produce the desired results unless an error correction term is included in the model. Thus, a VEC model has been implemented in this study as outlined in Granger [43] in

$$
\begin{aligned}
\Delta \mathrm{EXPG}_{t} & =\alpha+\lambda e_{t-1}+\sum_{i=1}^{n} b i \Delta \mathrm{EXPG}_{t-i} \sum_{i=1}^{m} c i \Delta \mathrm{FDIG}_{t-i} \\
& +\sum_{i=1}^{o} d i \Delta \mathrm{PDEN}_{t-i}+\sum_{i=1}^{p} e i \Delta \mathrm{GFCG}_{t-i} \\
& +\sum_{i=1}^{q} f i \Delta \mathrm{EXR}_{t-i}+\varepsilon_{t} .
\end{aligned}
$$

Notably, in this specification, the parameter $(\lambda)$ of the lagged error correction term $\left(e_{t-1}\right)$ indicates the long-run relationship in the variables being studied, and also the speed of adjustment from the short-run to the long-run equilibrium state. The appropriate lag-length of the variables (lag 1) has been selected through the final prediction error (FPE) criterion (following [44]) to overcome the over/under parameterization problem which may induce bias and inefficiency in the estimates. Notably, the parameter of the error correction term needs to be negative and statistically significant in terms of its associated tvalue to confirm the long-run equilibrium relationship in the variables. The changes in FDI, trade openness, domestic demand, and exchange rate cause the changes in exports when ci's, dis, ei's, and $f i$ 's are significant in terms of the $F$ test [45]. The stability of the VEC model has been ensured through the test of inverse roots of the AR characteristic polynomial. Besides, impulse response analysis has been performed by giving a shock of one standard deviation ( \pm 2 S.E. innovations) to FDI, domestic capital, exchange rate, and trade openness to visualize the duration of their effects on the export performance of Bangladesh. Finally, a variance decomposition analysis has been conducted to detect additional insights.

\section{Empirical Results and Discussion}

4.1. Descriptive Statistics. Table 2 presents the descriptive statistics of the variables under study. The Jarque-Bera test statistics fails to reject the null hypothesis of normal distribution of each variable, which confirms that the series are normally distributed. Besides, the numeric of kurtosis for each variable is found below (3), which indicates the normality of distribution.

The figure for skewness of each variable is found to be mild and positively skewed, except for the PDEN, which is negatively skewed slightly. The standard deviation of the series is found low when it is compared to the mean, which indicates a small coefficient of variation. In addition, the range of deviation between the maximum and minimum of each individual series is found to be reasonable in comparison to the mean. Finally, the mean over median ratio for each series is seen to be approximately one, except for the variable FDIG, which represents normality of distribution.
As a whole, the normality of distribution has been ensured in the study.

4.2. Stationarity Results. Tables 3 and 4 display the results of the unit root test both at the intercept and the intercept plus trend regression forms for the level and the first difference series, respectively, under the ADF and the PP tests. The ADF test statistics reveals that all the level series are nonstationary at their intercept and intercept plus trend regression forms, except for the PDEN series, which shows no unit root (in the case of the intercept plus trend) at the $5 \%$ level of significance. Likewise, the PP test statistics indicates nonstationarity in the level series, except for the GFCG series, which shows stationarity both at the intercept and intercept plus trend regression forms at the 5\% and $1 \%$ level of significance, respectively. This was done by comparing the calculated ADF and PP test statistics with their respective Mackinnon [46] critical values both at the $1 \%$ and $5 \%$ level of significance. Hence, the study proceeds to differencing the series to check their stationarity. At the first differencing, both the ADF and PP tests clearly reject the null hypothesis of unit root at the intercept and intercept plus trend cases either at the $1 \%$ or $5 \%$ level of significance. Clearly, all the series confirmed stationarity at the first differencing. Thus, it is concluded that they depict a same order of integration, that is, I (1) behavior. As a result, the study employs the JohansenJuselius cointegration test on the level series to detect the cointegration relationship in the variables.

4.3. Cointegration Results. Table 5 summarizes the results of the Johansen cointegration test both in the intercept and intercept plus trend regression forms. In both cases, the trace test and the maximum eigenvalue test yield one cointegrating equation at the $5 \%$ level of significance. Thus, it is concluded that the series are cointegrated, and a longrun equilibrium relationship exists among them. As a result, the study proceeds to run the vector error correction model, as outlined in (5).

4.4. Vector Error Correction (VEC) Model. Table 6 portrays the results of the vector error correction model. To run the VEC model, the appropriate lag-length (lag 1) of the variables has been selected through the FPE criterion (following [44]). Table 6 reveals that a long-run equilibrium relationship exists among the variables. This has been observed by the estimated parameter $(\lambda)$ of the error correction term $\left(e_{t-1}\right)$, which is negative as expected. In addition, FDI is found to have a significant short-term positive impact on the export performance of Bangladesh. Besides, a mild shortterm negative relationship is found to run between trade openness and exports, as the parameter of trade openness is traced significant approximately at the $10 \%$ level of significance. Such negative relationship is probably due to the high imports demand of Bangladesh, which caused the trade balance of the country to be negative for most of the years since the 1908s. On the other hand, the numeric of adjusted $R^{2}$ shows a low explanatory power of the model, meaning that other explanatory variables, not included in the study, may have significant influence on exports. The low 
TABLe 2: Descriptive statistics.

\begin{tabular}{|c|c|c|c|c|c|}
\hline & EXPG & FDIG & GFCG & EXR & PDEN \\
\hline Mean & 10.70737 & 0.489560 & 4.752917 & 43.13352 & 974.0180 \\
\hline Median & 9.940950 & 0.147312 & 4.560223 & 40.24500 & 974.3702 \\
\hline Maximum & 20.94193 & 1.466819 & 6.141041 & 69.03900 & 1247.350 \\
\hline Minimum & 3.279997 & -0.034744 & 4.136337 & 15.45400 & 694.4548 \\
\hline Std. Dev. & 5.362085 & 0.547602 & 0.529910 & 16.13736 & 169.0222 \\
\hline Skewness & 0.439155 & 0.569072 & 0.869562 & 0.184698 & -0.019984 \\
\hline Kurtosis & 1.918284 & 1.767174 & 2.769086 & 1.945019 & 1.783609 \\
\hline Jarque-Bera & 2.426920 & 3.519043 & 3.847345 & 1.561797 & 1.851506 \\
\hline Probability & 0.297167 & 0.172127 & 0.146070 & 0.457994 & 0.396233 \\
\hline Sum & 321.2210 & 14.68681 & 142.5875 & 1294.006 & 29220.54 \\
\hline Sum Sq. Dev. & 833.8068 & 8.696180 & 8.143347 & 7552.017 & 828486.3 \\
\hline Observations & 30 & 30 & 30 & 30 & 30 \\
\hline
\end{tabular}

TABLE 3: ADF unit root test for stationarity.

\begin{tabular}{lcccc}
\hline & & \multicolumn{2}{c}{ First difference } \\
& Intercept & Intercept plus trend & Intercept & Intercept plus trend \\
\hline EXPG & 1.015487 & -2.528736 & $-6.429114^{* * *}$ & $-7.213010^{* * *}$ \\
FDIG & -1.629711 & -2.963173 & $-6.178839^{* * *}$ & $-6.024192^{* * *}$ \\
GFCG & -1.186519 & -2.239703 & $-8.420725^{* * *}$ & $-7.845780^{* * *}$ \\
EXR & 0.389952 & -1.480079 & $-5.144659^{* * *}$ & $-5.098499^{* * *}$ \\
PDEN & -0.263170 & $-3.662075^{* *}$ & $-3.894389^{* * *}$ & $-3.692696^{* *}$ \\
\hline
\end{tabular}

TABLE 4: PP unit root test for stationarity.

\begin{tabular}{lcccc}
\hline & & Level & & \multicolumn{2}{c}{ First difference } \\
& Intercept & Intercept plus trend & Intercept & Intercept plus trend \\
\hline EXPG & 1.533520 & -2.528736 & $-6.392610^{* * *}$ & $-7.270672^{* * *}$ \\
FDIG & -1.505811 & -2.953038 & $-6.193253^{* * *}$ & $-6.035065^{* * *}$ \\
GFCG & $-3.280270^{* *}$ & $-6.152219^{* * *}$ & $-16.95955^{* * *}$ & $-17.41754^{* * *}$ \\
EXR & -0.650537 & -1.995489 & $-3.472748^{* * *}$ & $-3.349969^{* *}$ \\
PDEN & -2.468145 & -2.136851 & $-3.091485^{* *}$ & $-3.289305^{* *}$ \\
\hline
\end{tabular}

Note: the Mackinnon [46] critical values are -3.699871 and -2.976263 at $1 \%$ and $5 \%$ levels of significance, respectively. $* * *$ indicates significance at the $1 \%$ level and ${ }^{* *}$ at the $5 \%$ level.

TABLE 5: Johansen unrestricted cointegration rank test (trace and max-eigenvalue).

\begin{tabular}{lcccccccc}
\hline & \multicolumn{3}{c}{ Intercept } & \multicolumn{3}{c}{ Intercept plus trend } \\
& Eigen-value & Trace statistic & $0.5 \%$ CV & Prob. $^{* *}$ & Eigen-value & Trace statistic & $0.5 \%$ CV & Prob. ${ }^{* *}$ \\
\hline Trace test & 0.791 & 82.710 & 69.818 & $0.0033^{*}$ & 0.893 & 114.441 & 88.803 & $0.0002^{*}$ \\
Max-eigenvalue test & 0.791 & 43.853 & 33.876 & $0.0024^{*}$ & 0.791 & 62.591 & 38.331 & $0.0000^{*}$ \\
\hline
\end{tabular}

Note: (1)*denotes rejection of the hypothesis at the 0.05 level.

numeric of the F-statistic further indicates that there is not a strong feedback effect or the presence of Granger bidirectional causality between the variables. However, a unidirectional causality is traced between FDI and exports. As a whole, the VEC model shows that a long-run equilibrium relationship exists between FDI, trade openness, domestic demand, exchange rate, and export performance of Bangladesh without having any noticeable bi-directional causal relationship. The stability of the VEC model has been ensured through the test of inverse roots of the AR characteristic polynomial (Figure 4).

4.5. Impulse Response and Variance Decomposition. (Figure 5) reports impulse responses. It indicates how a 
TABLE 6: Estimates of VEC model.

\begin{tabular}{lcccc}
\hline Variable & Coefficient & Std. Error & $t$-statistic & Prob. \\
\hline$C$ & 15.69342 & 9.154058 & 1.714368 & 0.0894 \\
$e_{t-1}$ & -0.050018 & 0.054919 & -0.910753 & 0.3645 \\
$\Delta \operatorname{EXPG}(-1)$ & -0.331052 & 0.202225 & -1.637051 & 0.1046 \\
$\Delta \operatorname{EXR}(-1)$ & -0.080263 & 0.189708 & -0.423090 & 0.6731 \\
$\Delta$ FDIG $(-1)$ & 1.269648 & 0.582515 & 2.179598 & 0.0315 \\
$\Delta$ GFCG $(-1)$ & 0.190388 & 0.541548 & 0.351562 & 0.7259 \\
$\Delta$ PDEN $(-1)$ & -0.778147 & 0.470700 & -1.653171 & 0.1013 \\
$R$-squared & 0.333364 & Mean dependent var & 0.559707 \\
Adjusted $R$-squared & 0.142896 & S.D. dependent var & 0.984798 \\
S.E. of regression & 0.911725 & Akaike AIC & 2.865362 \\
Sum squared resid & 17.45610 & Schwarz SC & 3.198413 \\
Log likelihood & -33.11506 & F-statistic & 1.750240 \\
\hline
\end{tabular}

Table 7: Variance decomposition of exports.

\begin{tabular}{lccccc}
\hline Period & EXPG & FDIG & EXR & GFCG & PDEN \\
\hline 1 & 100.00 & 0.000 & 0.000 & 0.000 & 0.000 \\
2 & 67.00 & 32.67 & 0.316 & 0.000 & 0.000 \\
3 & 61.36 & 37.77 & 0.279 & 0.516 & 0.060 \\
4 & 52.61 & 44.85 & 0.718 & 1.651 & 0.156 \\
5 & 47.50 & 48.65 & 1.162 & 2.316 & 0.361 \\
6 & 43.96 & 51.14 & 1.471 & 2.772 & 0.647 \\
7 & 42.37 & 51.98 & 1.569 & 3.069 & 0.997 \\
8 & 42.04 & 51.81 & 1.537 & 3.245 & 1.360 \\
9 & 42.627 & 50.91 & 1.441 & 3.317 & 1.696 \\
10 & 43.73 & 49.63 & 1.336 & 3.315 & 1.969 \\
\hline
\end{tabular}

one-time positive shock of one standard deviation $( \pm 2$ S.E. innovations) to the FDI, domestic demand, exchange rate, and trade openness endures on the export performance of Bangladesh. It shows that the impulse response of FDI and exchange rate devaluation on exports are positive but diminishes as time goes on. However, the influence of FDI becomes slightly negative after the sixth period. On the other hand, the initial positive shock given to the domestic demand (GFCG) influences exports positively but becomes negative soon from the second year. Following the negative trend, it becomes insignificant from the fifth year onwards. In contrast, the response of trade openness (PDEN) to exports unearths a negative influence over time.

Table 7 presents the output of the variance decomposition analysis of exports. Table 7 reveals that the variance of exports is mainly fed on itself during the first four years. Thereafter, it declines but remains influential. In the second year, the variance of exports is decomposed into its own variance $(67 \%)$ followed by FDI (32.67\%). However, in subsequent years, the share of FDI increases and reaches to the maximum (51.98\%) in the seventh year. Then its influence declines, although it remains as a top factor in explaining exports. On the other hand, the share of trade openness, exchange rate, and domestic demand increases gradually from the second year, but it remains insignificant within the

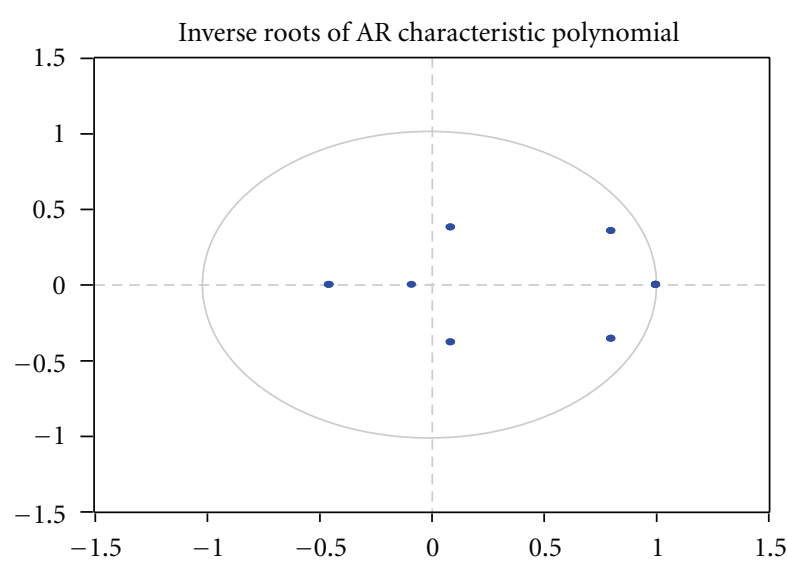

Figure 4: VEC stability test.

limit of $4 \%$. To conclude, the volatility of exports is mainly fed by its own variation followed by FDI.

\section{Concluding Remarks and Policy Lessons}

This study investigated the influence of FDI, trade openness, domestic demand, and exchange rate on the export performance of Bangladesh over the period of 1980-2009 by applying a vector error correction model. The results of the $\mathrm{ADF}$ and $\mathrm{PP}$ unit root tests indicated that all variables in the study were integrated in order one. The test statistics (trace and eigenvalue) of the Johansen cointegration test conducted on the intercept, and intercept plus trend regression forms indicated the presence of a cointegration relationship among the variables. In addition, the negative parameter of the error correction term confirmed that a long-run equilibrium relationship existed among the variables. Besides, a strong shortterm causal flow (unidirectional) was evidenced between FDI and exports. In addition to that, the trade openness demonstrates a very mild short-term influence on exports, as the coefficient of the trade openness was significant at the $10 \%$ level. However, the study did not trace any significant relationship between domestic demand, exchange rate, and exports. Moreover, the low value of the F-statistics did not indicate any short-term feedback relationship running in the system. Precisely, the VEC model traced a long-run equilibrium relationship in the variables under study without having any significant short-term causal flows between them, except for the FDI.

Furthermore, the impulse response function revealed a positive but diminishing influence of FDI and exchange rate on the export performance of Bangladesh. On the contrary, a mild negative influence was found for the case of domestic demand at its initial years, which became insignificant after the fourth year. However, trade openness revealed a negative influence on exports over time. Finally, the variance decomposition analysis revealed that the variance of exports was primarily caused by its own variance followed by the volume of FDI. It is to be noted that the role of FDI in explaining the volatility of exports was found to be more influential from the fifth year onwards. On the other hand, 
Response to Cholesky one S.D. innovations \pm 2 S.E.
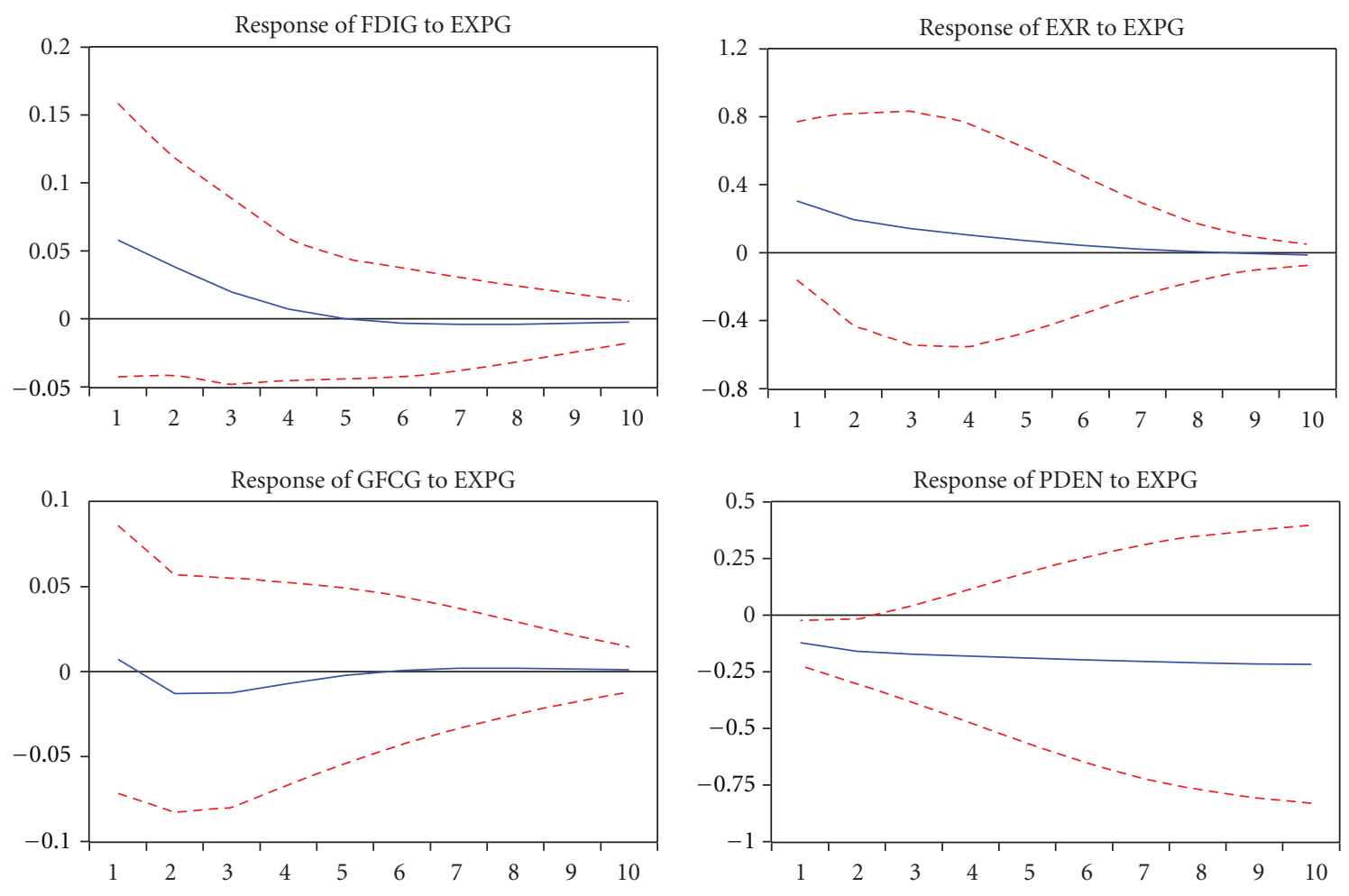

FIGURE 5: Impulse response of FDIG, EXR, GFCG, and PDEN on EXPG.

the role of domestic demand, exchange rate, and trade openness was found to be very minimal in causing the changes in exports.

The policy implications of this study can be summarized in the following points. First, there exists a long-term link in the nexus of FDI, domestic capital, exchange rate, trade openness, and exports performance of Bangladesh. This link indicates that the government of Bangladesh should utilize the above factors carefully on a long-run perspective to capitalize the benefits of the nexus properly. Second, FDI is probably an important factor in explaining the changes in exports. Thus, an FDI-led growth policy can be advocated to increase the country's overall exports and the rates of GDP growth as well. Third, trade openness tends to create an adverse impact on exports. Hence, the government should manage trade policies effectively. In fact, Bangladesh is a highly import-oriented economy with an unfavorable trade balance. Notably, three-fourths of its exports belong to a single sector-the readymade garments (RMG). Unfortunately, the net value addition of the RMG sector is limited to within 15 to $20 \%$. Thus, an appropriate trade policy that would neither influence higher import costs nor create an adverse effect on exports is sine qua non for Bangladesh. Fourth, the VEC-based Granger causality test did not reveal any short-term causal relationship between variables under study, except for the FDI. This also implies that the government of Bangladesh should design export and FDI policies in a way that they become complementary to one another.
In the end, it must be said that his study is not free from limitation. For instance, the study used a single indicator for trade openness, domestic demand, and exchange rate. Multiple indicators of the explanatory variables along with different measures of exports may generate different conclusions. Nonetheless, this study adopted the latest technique to gauge the link in the variables being studied, which may provide an important basis for future research in Bangladesh.

\section{References}

[1] A. B. Kumar, "FDI, trade openness, capital formation, and economic growth in Bangladesh: a linkage analysis," International Journal of Business and Management, vol. 6, no. 1, pp. 16-28, 2011.

[2] D. Papageorgiou, Liberalizing Foreign Trade: Lessons of Experience in the Developing World, Blackwell, Oxford, UK, 1991.

[3] J. Weiss, "Export response to trade reform: recent Mexican experience," Development Policy Review, vol. 10, no. 1, pp. 4360, 1992.

[4] A. U. Santos-Paulino, "Trade liberalization and export performance in selected developing countries," Studies in Economics 0012, Department of Economics, University of Kent, Canterbury, UK, 2000.

[5] N. Ahmed, "Export response to trade liberalization in Bangladesh: a cointegration analysis," Applied Economics, vol. 32, no. 8, pp. 1077-1084, 2000.

[6] J. Niemi, "The effects of trade liberalization on ASEAN agricultural commodity exports to the EU," in Proceedings of 
the 77th European Association of Agricultural Economists Seminar, No. 325 (EAAE'01), August 2001.

[7] M. A. Babatunde, "Can trade liberalization stimulate export performance in Sub-Saharan Africa?" Journal of International and Global Economic Studies, vol. 2, no. 1, pp. 68-92, 2009.

[8] M. R. Agosín, "Trade policy reform and economic performance: a review of the issues and some preliminary evidence," UNCTAD Discussion Papers 41, UNCTAD, Geneva, Switzerland, 1991.

[9] D. Greenaway and D. Sapsford, "What does liberalisation do for exports and growth?" Weltwirtschaftliches Archiv, vol. 130, no. 1, pp. 152-174, 1994.

[10] M. Shafaeddin, "The impact of trade liberalization on export and GDP in least developed countries," UNCTAD Discussion Papers 85, UNCTAD, Geneva, Switzerland, 1994.

[11] B. E. Moon, Exports, Outward-oriented Development, and Economic Growth, Department of International Relations, Leigh University, Bethlehem, Pa, USA, 1997.

[12] O. Morrissey and M. Andrew, Explaining Africa's Export Performance-Taking a New Look, https://www.gtap.agecon .purdue.edu/resources/download/2643.pdf, 2006.

[13] M. Dritsaki, C. Dritsaki, and A. Adamopoulos, "A causal relationship between trade, foreign direct investment, and economic growth for greece," American Journal of Applied Science, vol. 1, no. 3, pp. 230-235, 2004.

[14] R. K. Sharma, "Export growth in India: has FDI played a role?" Economic Growth Center Working Paper 816, Yale University, Connecticut, Conn, USA, 2000.

[15] X. Liu, C. Wang, and Y. Wei, "Causal links between foreign direct investment and trade in China," China Economic Review, vol. 12, no. 2-3, pp. 190-202, 2001.

[16] Y. Xing, "Why is China so attractive for FDI? The role of exchange rates," China Economic Review, vol. 17, no. 2, pp. 198-209, 2006.

[17] N. T. Xuan and Y. Xing, "Foreign direct investment and exports The experiences of Vietnam," Economics of Transition, vol. 16, no. 2, pp. 183-197, 2008.

[18] R. Svensson, "Effects of overseas production on home country exports: evidence based on Swedish multinationals," Weltwirtschaftliches Archiv, vol. 132, no. 2, pp. 304-328, 1996.

[19] P. A. Petri, M. G. Plummer, and J. H. Bergstrand, "The determinants of foreign direct investment: a survey with applications to the United States," in Economic Development and Cooperation in the Pacific Basin: Trade Investment and Environmental Issues, H. Lee and D. W. Roland-Holst, Eds., pp. 233 250, Cambridge University Press, New York, NY, USA, 1988.

[20] F. S. T. Hsiao and M. C. W. Hsiao, "FDI, exports, and GDP in East and Southeast Asia-Panel data versus time-series causality analyses," Journal of Asian Economics, vol. 17, no. 6, pp. 1082$1106,2006$.

[21] A. C. Arize, "The effects of exchange-rate volatility on U.S. exports: an empirical investigation," Southern Economic Journal, vol. 62, no. 1, pp. 34-43, 1996.

[22] A. C. Arize, T. Osang, and D. J. Slottje, "Exchange-rate volatility and foreign trade: evidence from thirteen LDC's," Journal of Business and Economic Statistics, vol. 18, no. 1, pp. 10-17, 2000.

[23] M. J. Bailey, G. S. Tavlas, and M. Ulan, "The impact of exchange-rate volatility on export growth: some theoretical considerations and empirical results," Journal of Policy Modeling, vol. 9, no. 1, pp. 225-243, 1987.

[24] A. Asseery and D. A. Peel, "The effects of exchange rate volatility on exports. Some new estimates," Economics Letters, vol. 37, no. 2, pp. 173-177, 1991.
[25] A. Abbott, A. C. Darnell, and L. Evans, "The influence of exchange rate variability on UK exports," Applied Economic Letters, vol. 8, no. 1, pp. 47-49, 2001.

[26] K. N. Wong and T. C. Tang, "Exchange rate variability and the export demand for Malaysia's semiconductors: an empirical study," Monash University Discussion Paper 13/07, 2007.

[27] Asian Development Bank (ADB), Asian Development Outlook, ADB, Manila, Philippines, 2005.

[28] Y. W. Lai, "The role of domestic demand in the economic growth in Malaysia: a cointegration analysis," International Economic Journal, vol. 18, no. 3, pp. 337-352, 2004.

[29] A. Chakrabarti, "The determinants of foreign direct investment: sensitivity analyses of cross-country regressions," Kyklos, vol. 54, no. 1, pp. 89-114, 2001.

[30] H. K. Nath, "Trade, foreign direct investment, and growth: evidence from transition economies," Comparative Economic Studies, vol. 51, no. 1, pp. 20-50, 2009.

[31] E. Asiedu, "On the determinants of foreign direct investment to developing countries: is Africa different?" World Development, vol. 30, no. 1, pp. 107-119, 2002.

[32] P.-L. Tsai, "Determinants of foreign direct investment and its impact on economic growth," Journal of Economic Development, vol. 19, no. 1, pp. 137-163, 1994.

[33] H. Yanikkaya, "Trade openness and economic growth: a cross-country empirical investigation," Journal of Development Economics, vol. 72, no. 1, pp. 57-89, 2003.

[34] J. D. Sachs and W. Andrew, "Economic reform and the process of global integration," Brookings Paper on Economic Activity, vol. 26, no. 1, pp. 1-118, 1995.

[35] P. Sahoo, "Foreign direct investment in South Asia: policy, trends, impact and determinants," ADB Institute Discussion Paper 56, 2006.

[36] T. Beck and R. Levine, "Stock markets, banks, and growth: panel evidence," Journal of Banking and Finance, vol. 28, no. 3, pp. 423-442, 2004.

[37] W. A. Fuller, Introduction to Statistical Time Series, John Wiley and Sons, New York, NY, USA, 1976.

[38] D. A. Dickey and W. A. Fuller, "Distributions of the estimators for autoregressive time series with a unit root," Journal of the American Statistical Association, vol. 74, no. 366, pp. 10571072, 1979.

[39] P. C. B. Phillips and P. Perron, "Testing for a unit root in time series regression," Biometrika, vol. 75, no. 2, pp. 335-346, 1988.

[40] S. Johansen, "Statistical analysis of cointegration vectors," Journal of Economic Dynamics and Control, vol. 12, no. 2-3, pp. 231-254, 1988.

[41] S. Johansen, "Estimation and hypothesis testing of cointegration vectors in Gaussian vector autoregressive models," Econometrica, vol. 59, no. 6, pp. 1551-1580, 1991.

[42] S. Johansen, Likelihood-based inference in Cointegrated Vector Autoregressive Models, Oxford University Press, New York, NY, USA, 1995.

[43] C. W. J. Granger, "Some recent developments in a concept of causality," Journal of Econometrics, vol. 39, no. 1-2, pp. 199211, 1988.

[44] H. Akaike, "Power spectrum estimation through autoregressive model fitting," Annals of the Institute of Statistical Mathematics, vol. 21, no. 1, pp. 407-419, 1969.

[45] M. Bahmani-Oskooee and S. Payesteh, "Budget deficits and the value of the dollar: an application of cointegration and error-correction modeling," Journal of Macroeconomics, vol. 15, no. 4, pp. 661-677, 1993. 
[46] J. G. Mackinnon, "Numerical distribution functions for unit root and cointegration tests," Journal of Applied Econometrics, vol. 11, no. 6, pp. 601-618, 1996.

[47] O. P. Chimobi and U. C. Uche, "Export, domestic demand and economic growth in Nigeria: granger causality analysis," European Journal of Social Sciences, vol. 13, no. 2, pp. 211-218, 2010.

[48] N. Prasanna, "Impact of foreign direct investment on export performance in India," Journal of Social Science, vol. 24, no. 1, pp. 65-71, 2010.

[49] J. Martinez-Martin, "On the dynamics of exports and FDI: the Spanish internationalization process," Working Paper 2010/10, Research Institute of Applied Economics, Barcelona, Spain, 2010.

[50] J. Duasa, "Asymmetric cointegration relationship between real exchange rate and trade variables: the case of Malaysia," MPRA Paper 14535, 2009.

[51] A. M. Njong, "Investigating the effects of foreign direct investment on export growth in Cameroon," in Proceedings of the UNECA Ad-hoc Expert Group Meeting Paper, Addis Ababa, Ethiopia, November 2008.

[52] H.-T. Wong, "Exports and domestic demand: some empirical evidence in ASEAN 5," Labuan Bulletin of International Business and Finance, vol. 6, pp. 39-55, 2008.

[53] M. G. Mortaza and C. D. Narayan, "Foreign direct investment, trade liberalization and economic growth: empirical evidence from South Asia and implications for Bangladesh," Working Paper Series 0712, Policy Analysis Unit, Bangladesh Bank, Dhaka, Bangladesh, 2007. 


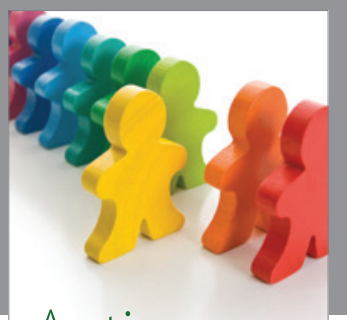

Autism

Research and Treatment
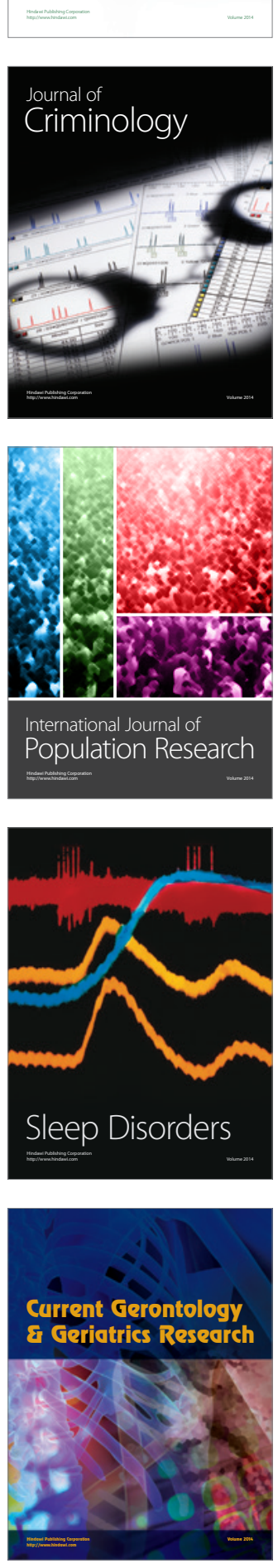
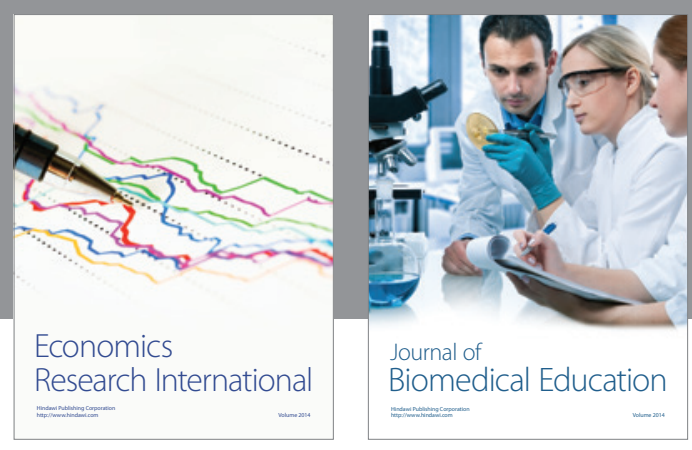

Journal of

Biomedical Education

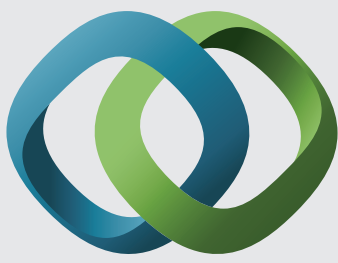

\section{Hindawi}

Submit your manuscripts at

http://www.hindawi.com
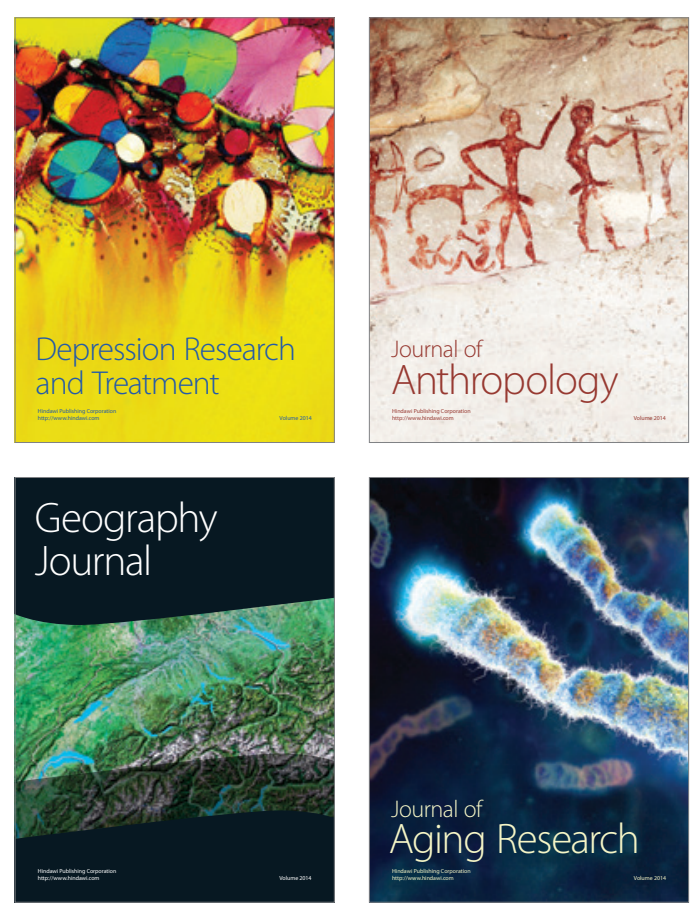

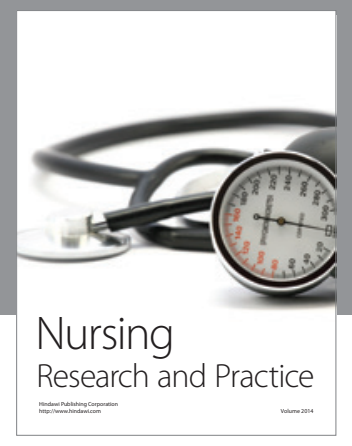

Nursing

Research and Practice

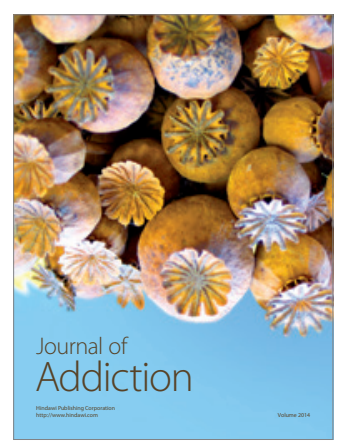

Child Development

Research

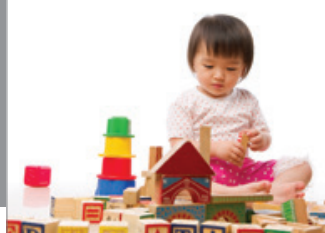

迥
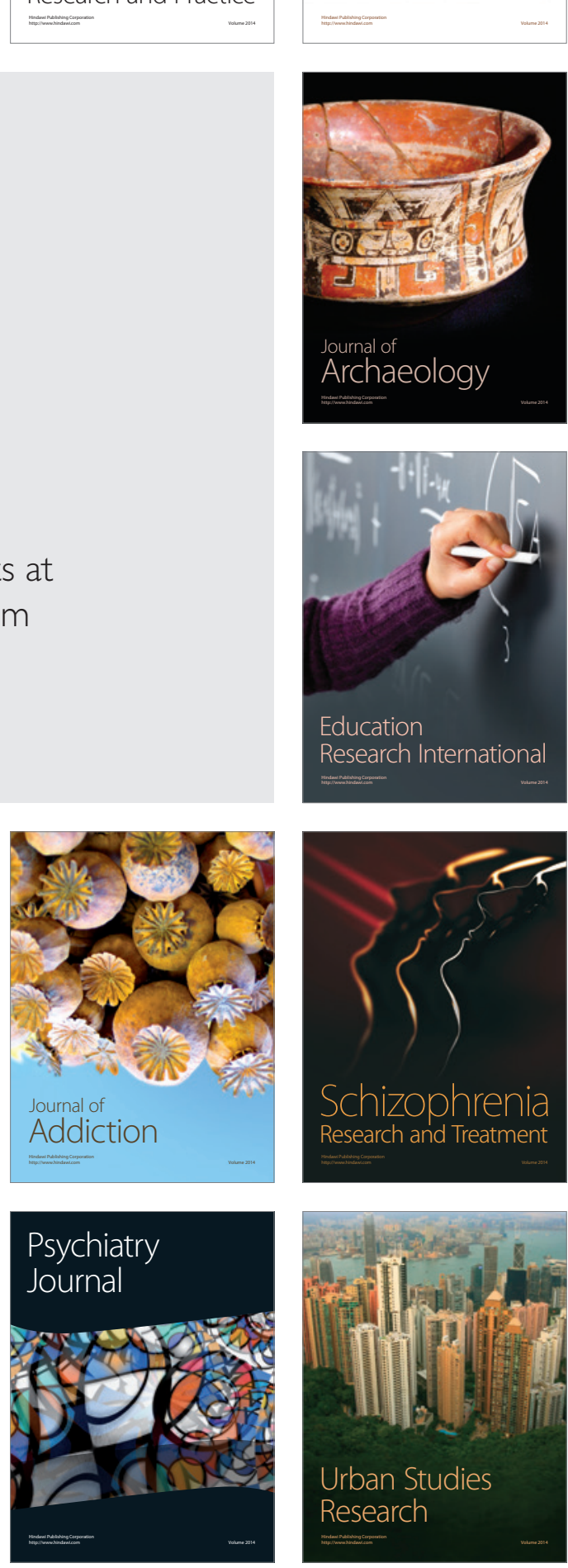